\title{
Ethidium Binding to Salmonella enterica ser. Typhimurium Cells and Salmon Sperm DNA
}

\author{
Sandra Sakalauskaite ${ }^{1}$, Valeryia Mikalayeva ${ }^{1,2}$ (D) and Rimantas Daugelavičius ${ }^{1, *([)}$ \\ 1 Department of Biochemistry, Faculty of Natural Sciences, \\ Vytautas Magnus University, 44404 Kaunas, Lithuania; Sandra.Sakalauskaite@vdu.lt (S.S.); \\ Valeryia.Mikalayeva@lsmuni.lt (V.M.) \\ 2 Institute of Cardiology, Lithuanian University of Health Sciences, 50162 Kaunas, Lithuania \\ * Correspondence: rimantas.daugelavicius@vdu.lt; Tel.: +370-37-327917
}

Citation: Sakalauskaitè, S.; Mikalayeva, V.; Daugelavičius, R. Ethidium Binding to Salmonella enterica ser. Typhimurium Cells and Salmon Sperm DNA. Molecules 2021, 26, 3386. https://doi.org/10.3390/ molecules26113386

Academic Editor: Jean-Marc Sabatier

Received: 16 April 2021

Accepted: 31 May 2021

Published: 3 June 2021

Publisher's Note: MDPI stays neutral with regard to jurisdictional claims in published maps and institutional affiliations.

Copyright: (c) 2021 by the authors. Licensee MDPI, Basel, Switzerland. This article is an open access article distributed under the terms and conditions of the Creative Commons Attribution (CC BY) license (https:// creativecommons.org/licenses/by/ $4.0 /)$.

\begin{abstract}
Bacterial resistance to antibiotics due to increased efficiency of the efflux is a serious problem in clinics of infectious diseases. Knowledge of the factors affecting the activity of efflux pumps would help to find the solution. For this, fast and trustful methods for efflux analysis are needed. Here, we analyzed how the assay conditions affect the accumulation of efflux indicators ethidium $\left(\mathrm{Et}^{+}\right)$and tetraphenylphosphonium in Salmonella enterica ser. Typhimurium cells. An inhibitor phenylalanyl-arginyl- $\beta$-naphtylamide was applied to evaluate the input of RND family pumps into the total efflux. In parallel to spectrofluorimetric analysis, we used an electrochemical assessment of $\mathrm{Et}^{+}$concentration. The results of our experiments indicated that $\mathrm{Et}^{+}$fluorescence increases immediately after the penetration of this indicator into the cells. However, when cells bind a high amount of $\mathrm{Et}^{+}$, the intensity of the fluorescence reaches the saturation level and stops reacting to the accumulated amount of this indicator. For this reason, electrochemical measurements provide more trustful information about the efficiency of efflux when cells accumulate high amounts of $\mathrm{Et}^{+}$. Measurements of $\mathrm{Et}^{+}$interaction with the purified DNA demonstrated that the affinity of this lipophilic cation to DNA depends on the medium composition. The capacity of DNA to bind $\mathrm{Et}^{+}$ considerably decreases in the presence of $\mathrm{Mg}^{2+}$, Polymyxin $\mathrm{B}$ or when DNA is incubated in high ionic strength media.
\end{abstract}

Keywords: ethidium; tetraphenylphosphonium; multidrug resistance; outer membrane permeability; efflux inhibitor; phenylalanyl-arginyl- $\beta$-naphtylamide; Polymyxin B

\section{Introduction}

Bacterial resistance to antimicrobials is a worldwide problem. The key part of the resistance is efflux pumps (EPs) [1]. AcrAB-TolC complex in Salmonella enterica ser. Typhimurium belongs to the resistance-nodulation-division (RND) family of efflux transporters. EPs of this family are the most important in Gram-negative bacteria because they extrude clinically relevant drugs [2]. It is necessary to understand the peculiarities of efflux to overcome this problem. Such knowledge would be essential for more efficient usage of the available antibacterials and for the discovery of new ones.

Lipophilic cations ethidium $\left(\mathrm{Et}^{+}\right)$and tetraphenylphosphonium $\left(\mathrm{TPP}^{+}\right)$are wellknown EP substrates [3-6]. Transmembrane difference of electrical potential $(\Delta \psi$, negative inside) drives the accumulation of lipophilic cations in the bacterial cytosol. Intracellular components bind a low amount of $\mathrm{TPP}^{+}$[7], and therefore, this cation can be used to estimate the $\Delta \psi$ in bacteria and mitochondria [8]. The specific feature of $\mathrm{Et}^{+}$is the affinity of this cation to the double helix of nucleic acids. Intercalation of $\mathrm{Et}^{+}$into the double-stranded DNA or RNA considerably increases the fluorescence of this compound [9]. Therefore, measurements of $\mathrm{Et}^{+}$fluorescence is one of the most popular methods for assay of EP activity in bacteria [10-13]. The intensity of fluorescence correlates with the amount of $\mathrm{Et}^{+}$bound to DNA, and the latter is proportional to the intracellular concentration of this indicator. 
Measurements of $\mathrm{Et}^{+}$fluorescence is a convenient method for analysis of the competition between efflux substrates $[14,15]$ because it is possible to use several efflux indicators in the same sample. However, $\mathrm{Et}^{+}$fluorescence in wells of the plates proceeds slower than the electrochemically assayed binding of this indicator to bacteria [14]. Besides this, a gradual decrease in the fluorescence was observed in experiments with bacteria [13,14], although the cell-bound $\mathrm{Et}^{+}$was not destructed [13].

Here, we investigated the fluorescence of $\mathrm{Et}^{+}$in suspensions of $S$. typhimurium cells at conditions close to ones used for the electrochemical monitoring of interaction of this indicator with the same bacteria. During the potentiometric analysis using the $\mathrm{Et}^{+}$selective electrode, samples of the bacterial suspension were taken from the vessels for immediate assays of the fluorescence of this indicator. In parallel to the monitoring of $\mathrm{Et}^{+}$interaction with the cells, at the same incubation conditions, the electrochemical measurements of $\mathrm{TPP}^{+}$accumulation in bacteria were performed. An efflux inhibitor phenylalanyl-arginyl$\beta$-naphtylamide (PA $\beta N$ ) was used to analyze the role of RND-family pumps in extrusion of the indicators from intact and EDTA- or Polymyxin B-permeabilized cells. Results of experiments indicated that fluorescence of $\mathrm{Et}^{+}$reaches the saturation level when millimolar concentrations of this cation accumulate in the cytosol of S. typhimurium cells. Measurements of $\mathrm{Et}^{+}$interaction with the purified DNA showed that the ability of DNA to bind $\mathrm{Et}^{+}$depends on the composition of the incubation medium. The presence of $\mathrm{Mg}^{2+}$ or Polymyxin B (PMB), or just increase in the ionic strength of the medium considerably decrease $\mathrm{Et}^{+}$binding to DNA.

\section{Results}

\subsection{Simultaneous Measurements of $\mathrm{Et}^{+}$and $\mathrm{TPP}^{+}$Interaction with S. typhimurium Cells}

The results of our previous experiments indicated [14] that fluorescence of $\mathrm{Et}^{+}$in S. typhimurium suspensions correlates with the amount of this indicator bound to the cells. However, there were considerable differences in the kinetics and the amplitude of changes, registered by the spectrofluorimetric and the electrochemical techniques. This can be explained by the differences in cell incubation conditions during assays in vessels for the electrochemical measurements and in plate wells for the registration of $\mathrm{Et}^{+}$fluorescence. To reduce the impact of incubation conditions, we combined electrochemical and spectrofluorimetric analyses: during the electrochemical monitoring of extracellular $\mathrm{Et}^{+}$concentration, samples of S. typhimurium suspension were taken to microtubes, and the fluorescence was immediately measured. In parallel, the electrochemical monitoring of $\mathrm{TPP}^{+}$concentration in the suspensions of cells incubated at the same conditions was performed (Figure 1).

The addition of $S$. typhimurium cells to $100 \mathrm{mM}$ Tris buffer had a very weak effect on $\mathrm{Et}^{+}$fluorescence because of the outer membrane (OM) barrier and efflux pumps. The wild-type (wt) cells accumulated very low amounts of both lipophilic cations (Figure 1a,b), but concentrations of the indicators in the medium considerably decreased, and the fluorescence of $\mathrm{Et}^{+}$increased when efflux pump mutant $\Delta$ tolC cells were added (Figure 1c,d). Chelator of the divalent cations EDTA permeabilized the OM and induced the accumulation of the indicator cations by the cells of both strains, strongly increasing the fluorescence of $\mathrm{Et}^{+}$in bacterial suspensions. The obtained results revealed that there was no considerable difference between the accumulated amounts of the indicators in S. typhimurium wt cells, while $\Delta$ tolC mutant cells before permeabilization accumulated twice more $\mathrm{Et}^{+}$ than $\mathrm{TPP}^{+}$( 8 and $3.6 \mathrm{nmol}$ respectively). The total amounts of accumulated indicators in EDTA-permeabilized cells were rather similar (Figure 1). 


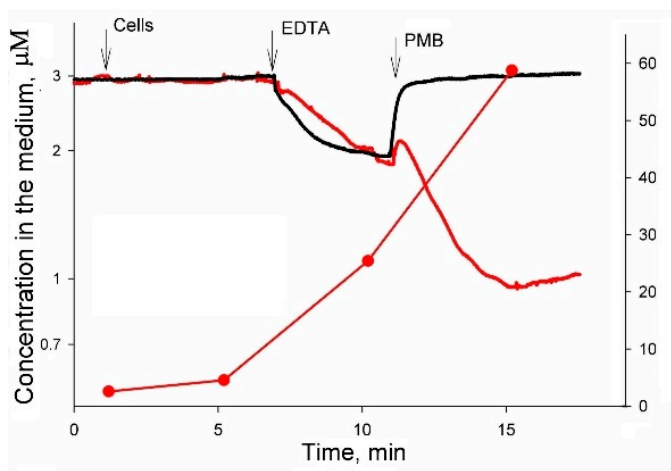

(a)

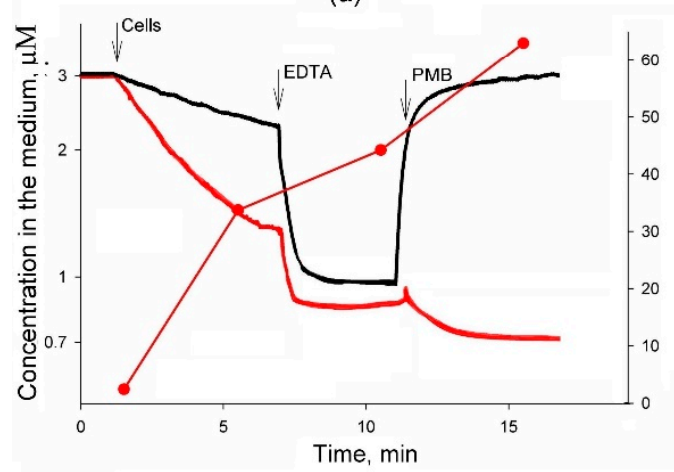

(c)

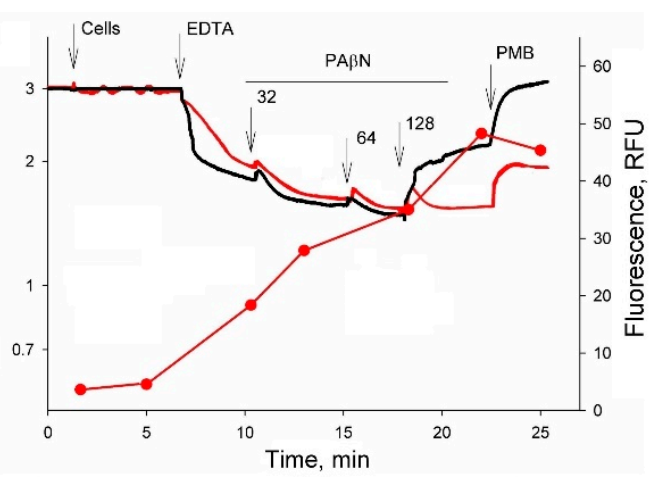

(b)

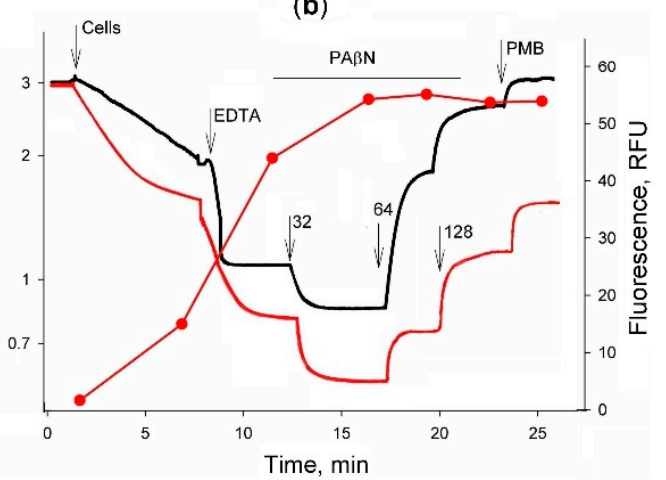

(d)

$-\mathrm{Et}^{+} \quad-\mathrm{TPP}^{+} \quad$ Fluorescence of $\mathrm{Et}^{+}$

Figure 1. The accumulation of $\mathrm{Et}^{+}$and $\mathrm{TPP}^{+}$ions in S. typhimurium SL1344 wt (a,b) and $\Delta$ tolC mutant (c,d) cells during simultaneous potentiometric and spectrofluorimetric assays. The measurements were performed at $37{ }^{\circ} \mathrm{C}$ in $100 \mathrm{mM}$ Tris $/ \mathrm{HCl}$ buffer, $\mathrm{pH} 8.0$, containing $0.1 \%$ glucose. The concentrated cell suspensions were added to obtain $\mathrm{OD}_{600}$ of 1 . EDTA was added to $1 \mathrm{mM}$ and PMB to $50 \mathrm{mg} / \mathrm{L}$. The final concentrations of PA $\beta \mathrm{N}(\mu \mathrm{M})$ are indicated in the figure $(\mathbf{b}, \mathbf{d})$. Samples of $75 \mu \mathrm{L}$ each were taken from the vessels to microtubes just before the indicated additions, and intensities of the fluorescence were immediately measured.

The most widely used inhibitor of the RND family pumps PA $\beta N$ increased the accumulation of $\mathrm{Et}^{+}$and $\mathrm{TPP}^{+}$, and at the same time, stimulated $\mathrm{Et}^{+}$fluorescence. The maximal level of fluorescence was reached when PA $\beta N$ concentration in wt cell suspension was $128 \mu \mathrm{M}$, but only $32 \mu \mathrm{M}$ were needed for the maximal accumulation and fluorescence in the case of $\Delta$ tolC mutant cells (see Figure $1 b, d$ ). At higher PA $\beta N$ concentrations, the fluorescence of $\mathrm{Et}^{+}$did not change, although the curves of electrochemical measurements indicated the leakage of indicators to the medium (see Figure 1d). It should be noted that $\mathrm{Et}^{+}$leakage was electrochemically registered when the intensity of the fluorescence was rather stable and stayed at the maximum level (see Figure 1d).

Depending on the concentration, polycationic antibiotic PMB permeabilizes the OM and depolarizes the plasma membrane (PM) [16]. Results of the potentiometric measurements demonstrated that effects of $\mathrm{PMB}$ on $\mathrm{Et}^{+}$accumulation in S. typhimurium cells of both strains were dependent on the presence of PA $\beta N$ : PMB was able to induce an additional accumulation of $\mathrm{Et}^{+}$in the absence of PA $\beta \mathrm{N}$ (see Figure 1a,c), but the leakage of this indicator from cells was observed in the presence of the efflux inhibitor (see Figure 1b,d). In the absence of PA $\beta N$, the addition of PMB considerably increased the fluorescence of $\mathrm{Et}^{+}$(see Figure 1a,c).

In the presence of $\mathrm{PA} \beta \mathrm{N}, \mathrm{Et}^{+}$fluorescence was at the maximal level, and the addition of PMB had no effect on it (see Figure 1b,d). Correlation between the accumulated amount of $\mathrm{Et}^{+}$and the intensity of fluorescence was lost when the amount of the cells bound to $\mathrm{Et}^{+}$ reached $\sim 13 \mathrm{nmol}$ (see Figure 1d). The fluorescence of $\mathrm{Et}^{+}$did not change when the PA $\beta \mathrm{N}$ concentration in the medium increased from 32 to $128 \mu \mathrm{M}$, although the cell-accumulated amount of this cation decreased by $34 \%$ (see Figure 1d). 
These results indicate that PMB induces an additional accumulation of $\mathrm{Et}^{+}$when the distribution of this ion between cells and the incubation medium is not in equilibrium. Permeabilization of the OM by EDTA and inhibition of the efflux by PA $\beta N$ led to the equilibrium distribution of $\mathrm{TPP}^{+}$across the PM, enabling calculations of the $\Delta \psi$. In the case of wt cells, the maximal level of $\Delta \psi$, calculated according to the amount of accumulated $\mathrm{TPP}^{+}$in the presence of $64 \mu \mathrm{M} \mathrm{PA} \beta \mathrm{N}$, was $209 \pm 3 \mathrm{mV}$. In $\Delta$ tolC cells, the highest amount of $\mathrm{TPP}^{+}$was accumulated in the presence of $32 \mu \mathrm{M} \mathrm{PA} \beta \mathrm{N}$, and the calculated $\Delta \psi$ at these conditions was $230 \pm 1 \mathrm{mV}$. The binding of $\mathrm{Et}^{+}$to DNA does not allow to assay the intracellular concentration of the unbound form of this indicator and, correspondingly, to calculate $\Delta \psi$.

\subsection{Et ${ }^{+}$Binding to S. typhimurium Cells}

According to Rodrigues and colleagues [15], the possibility to use $\mathrm{Et}^{+}$as a fluorescent efflux indicator depends on the concentration of this ion in the medium. Higher concentrations of $\mathrm{Et}^{+}$, exceeding the capacity of the efflux pumps, are expected to result in increased accumulations, which, if sufficiently high, can result in ethidium reaching DNA where it can readily intercalate.

We decided to explore in more detail the dependence of the interaction of $\mathrm{Et}^{+}$with S. typhimurium cells on the concentration of this indicator. Taking higher initial $\mathrm{Et}^{+}$concentrations in the medium, we added intact or heat-killed cells and determined amounts of $\mathrm{Et}^{+}$accumulated by the cells (see Figure 2). Additions of EDTA to Tris medium induced accumulation of $\mathrm{Et}^{+}$by the cells, but the permeabilizing effect of this chelator was considerably weaker compared to the $3 \mu \mathrm{M}$ indicator containing medium (see Figure $1 \mathrm{a}, \mathrm{b}$ ). PMB induced a considerably stronger accumulation, but the amount of $\mathrm{Et}^{+}$bound was not high compared to the cells, preliminary treated with Tris/EDTA (see Figure 2b). In the absence of EDTA, PMB was more efficient, and the equilibrium distribution of $\mathrm{Et}^{+}$across the cell envelope was achieved in two minutes after PMB addition (see Figure $2 b$ ). At lower concentrations, i.e., $24 \mu \mathrm{M}$, the PMB-induced accumulation of $\mathrm{Et}^{+}$was not stable, and a release of this indicator followed the accumulation (see Figure $2 \mathrm{~b}$ ). $\mathrm{Et}^{+}$was only released to the medium after the second PMB addition. The results of these experiments indicate that in high concentrations, there is no direct correlation between the cell-bound amount of $\mathrm{Et}^{+}$and the initial concentration of the indicator in the medium.

Because of the heat-inactivated efflux and permeabilized OM, after heating envelope of the cells demonstrated a very weak barrier to $\mathrm{Et}^{+}$. In spite of the absence $\Delta \psi$, accumulating cations in the cytosol, the heat-inactivated cells bound maximum amount $\mathrm{of} \mathrm{Et}^{+}(190 \mathrm{nmol}$, when the initial concentration was $96 \mu \mathrm{M}$, see Figure 2c). The accumulated amount of Et ${ }^{+}$ in heat-inactivated cells was stable, did not changed during the incubation period. Starting the same initial concentration, the heat-inactivated cells were binding $24-50 \% \mathrm{more} \mathrm{Et}^{+}$ compared to EDTA- and/or PMB-permeabilized cells (compare Figure 2b,c). Changes in intracellular DNA arrangement during the heating could be the reason for the higher amount of $\mathrm{Et}^{+}$bound and stronger fluorescence. 


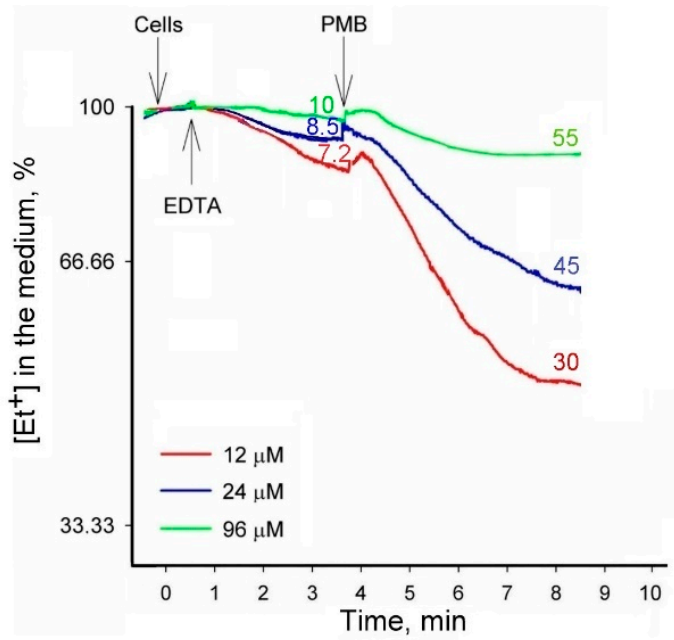

(a)

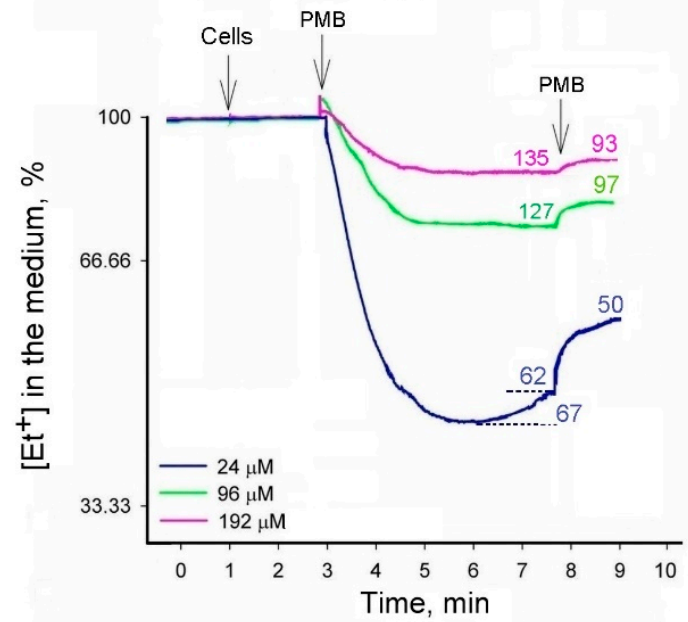

(b)

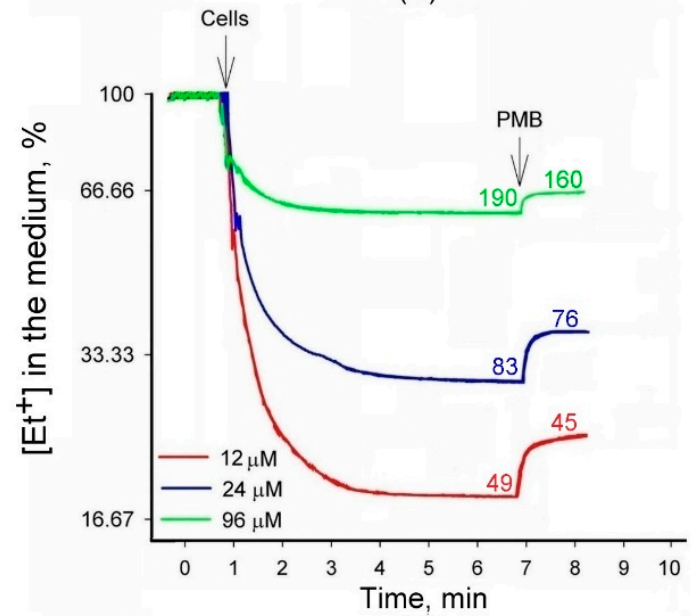

(c)

Figure 2. The binding of $\mathrm{Et}^{+}$to intact and heat-inactivated S. typhimurium SL1344 wt cells incubated with different concentrations of this cation. Concentrated intact $(\mathbf{a}, \mathbf{b})$ or heat-inactivated (c) cell suspensions were added to $100 \mathrm{mM}$ Tris $/ \mathrm{HCl}$ buffer, $\mathrm{pH} 8.0$, containing $0.1 \%$ glucose, to obtain $\mathrm{OD}_{600}$ of 1 . On Y-axes, $\mathrm{Et}^{+}$concentrations are presented in \% of the initial ones. The initial concentrations of $\mathrm{Et}^{+}$are indicated in the figure. PMB was added to the final concentration of $50 \mathrm{mg} / \mathrm{L}(\mathbf{a}, \mathrm{c})$ or 50 and $100 \mathrm{mg} / \mathrm{L}(\mathbf{b})$, EDTA to $1 \mathrm{mM}$. Numbers next to the curves indicate the amount (nmol) of $\mathrm{Et}^{+}$bound to the cells. The experiment was performed at $37^{\circ} \mathrm{C}$. 
In order to get more information on the role of envelope barrier in $\mathrm{Et}^{+}$binding to the cells, experiments with intact and Tris/EDTA-permeabilized cells, as well as purified salmon sperm DNA were performed. Cells or DNA were added to 100- or 400-mM Tris buffer containing $3 \mu \mathrm{M} \mathrm{Et}^{+}$. In both buffers, intact cells did not bind $\mathrm{Et}^{+}$, and slow accumulation of this indicator was observed only after PMB addition. The concentration of $\mathrm{Et}^{+}$in the medium immediately decreased after the addition of Tris/EDTA-permeabilized cells, but after the fast initial accumulation, a slow release of the indicator was observed, more clearly expressed in $100 \mathrm{mM}$ buffer (see Figure 3). PMB induced an additional release of the cell-bound $\mathrm{Et}^{+}$. In general, the cells in $400 \mathrm{mM}$ buffer accumulated less $\mathrm{Et}^{+}$compared to ones incubated in $100 \mathrm{mM}$ Tris. The permeabilized cells in $400 \mathrm{mM}$ buffer accumulated

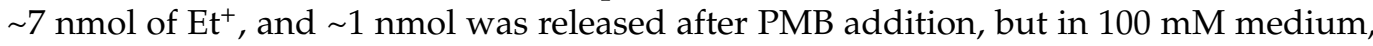
these values were around $10 \mathrm{nmol}$ and $3 \mathrm{nmol}$, correspondingly. In both media, after the addition of $\mathrm{PMB}$, the intact cells accumulated higher amounts of $\mathrm{Et}^{+}$compared to the preliminary permeabilized cells.

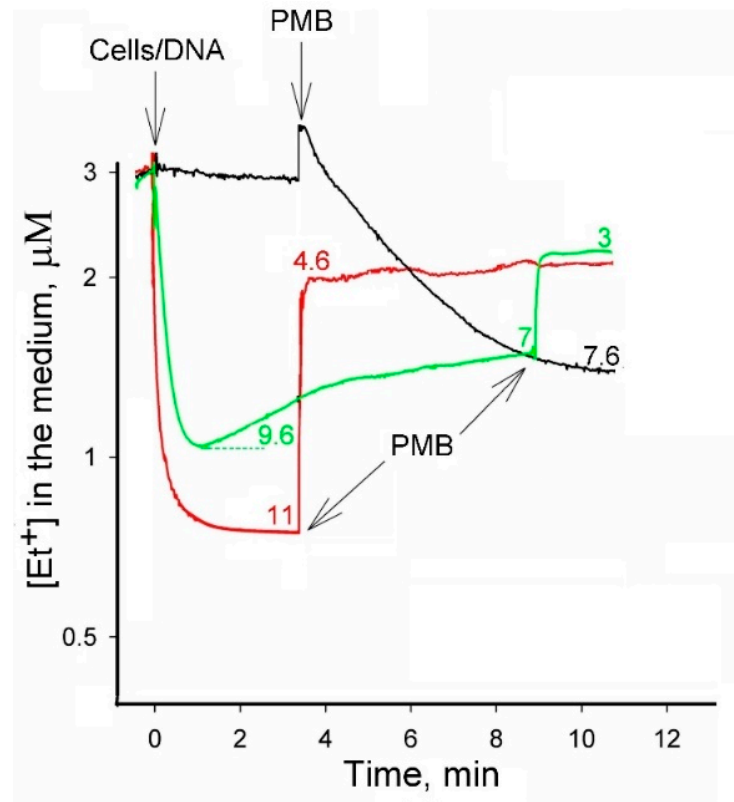

(a)

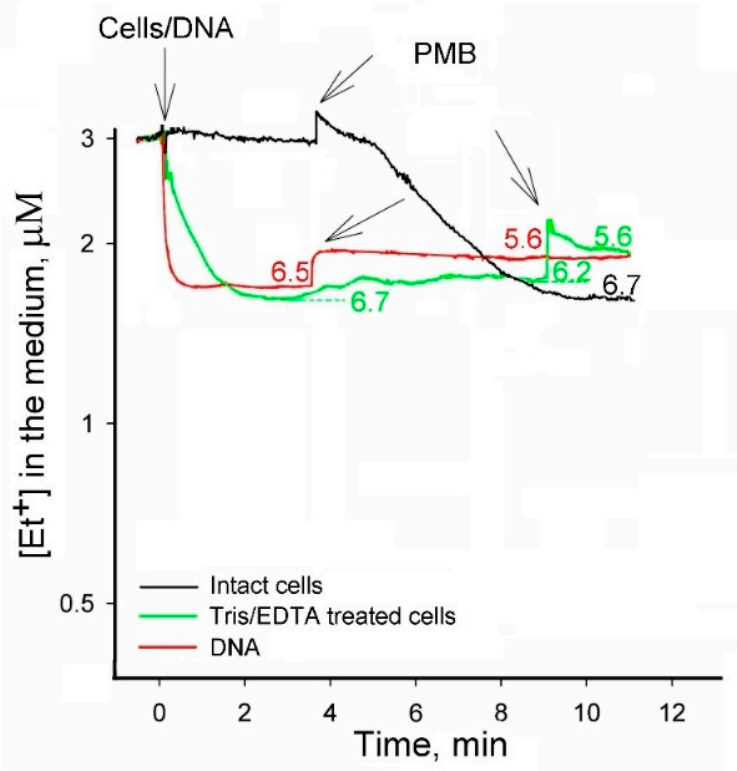

(b)

Figure 3. The binding of $\mathrm{Et}^{+}$to intact or Tris/EDTA-permeabilized S. typhimurium SL1344 wt cells and salmon sperm DNA. The experiments were performed at $37^{\circ} \mathrm{C}$ in $100 \mathrm{mM}$ (a) or $400 \mathrm{mM}$ (b) Tris/ $\mathrm{HCl}$ buffer, $\mathrm{pH} 8.0$, containing $0.1 \%$ glucose. Concentrated suspensions of intact or Tris/EDTA-treated cells were added to obtain $\mathrm{OD}_{600}$ of 1 . Red curves demonstrate the addition of $100 \mu \mathrm{g}$ of salmon sperm DNA. PMB was added to the final concentration of $50 \mathrm{mg} / \mathrm{L}$. Numbers next to the curves indicate the amount (nmol) of $\mathrm{Et}^{+}$bound.

After the addition of DNA to the medium, a very fast decrease in the $\mathrm{Et}^{+}$concentration to the stabile level was observed, and in $100 \mathrm{mM}$ Tris, the bound amount of $\mathrm{Et}^{+}(11 \mathrm{nmol})$ was considerably higher than in $400 \mathrm{mM}$ buffer $(\sim 6.5 \mathrm{nmol})$. In both media, PMB released a considerable amount of bound $\mathrm{Et}^{+}$, and the left amount of the indicator bound in $100 \mathrm{mM}$ buffer was even a bit lower than in $400 \mathrm{mM}$ (around 4.6 and $5.6 \mathrm{nmol}$, correspondingly. The amount of $\mathrm{Et}^{+}$bound to DNA after PMB addition was very close to the amount left in Tris/EDTA-treated cells at the same conditions (see Figure 3).

\subsection{Binding of $E t^{+}$to DNA in Solutions of Various Composition}

To learn more about how $\mathrm{Et}^{+}$binding to DNA depends on the composition of the medium, we extended the potentiometric analysis of this process. During the first experiment, we measured the amount of $\mathrm{Et}^{+}$bound to a certain amount $(100 \mu \mathrm{g})$ of DNA, increasing the concentration of this indicator in $100 \mathrm{mM}$ Tris buffer. We elucidated that 
saturation level was reached at $60 \mu \mathrm{M}$ and higher concentrations of this cation after binding of $50 \mathrm{nmol}$ of $\mathrm{Et}^{+}$to $100 \mu \mathrm{g}$ of DNA (see Figure 4).

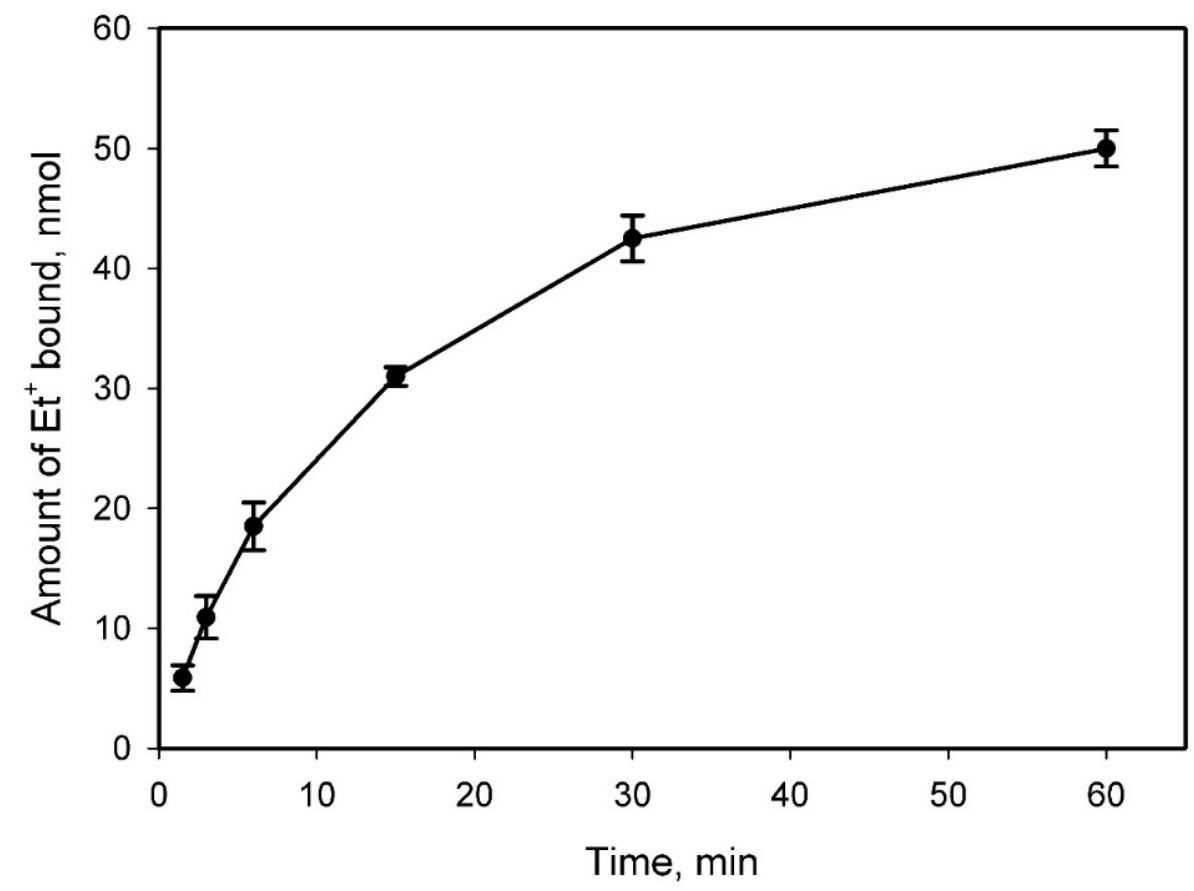

Figure 4. The dependence of the amount of $\mathrm{Et}^{+}$bound to DNA on the concentration of this cation in the medium. In total, $100 \mu \mathrm{g}$ of salmon sperm DNA was added to various concentrations of $\mathrm{Et}^{+}$ containing $100 \mathrm{mM}$ Tris/ $\mathrm{HCl}$ buffer, $\mathrm{pH}$. The experiment was performed at $37^{\circ} \mathrm{C}$.

Continuing experiments with the purified DNA, we explored how changes in the medium composition could affect the binding of $\mathrm{Et}^{+}$to DNA. In experiments with DNA solutions, the initial fluorescence of DNA-bound $\mathrm{Et}^{+}$in $400 \mathrm{mM}$ Tris buffer was $20 \%$ lower compared to $100 \mathrm{mM}$ Tris $/ \mathrm{HCl}$. During the monitoring period, the fluorescence gradually decreased, and after 25-30 min, it was 20-30\% lower compared to the initial level (see Figure $5 \mathrm{a}, \mathrm{b})$. The presence of $\mathrm{TPP}^{+}$or $\mathrm{PA} \beta \mathrm{N}$ in DNA solutions had a weak effect on $\mathrm{Et}^{+}$ fluorescence. However, in the presence of $\mathrm{PMB}$ or $\mathrm{Mg}^{2+}$ (also $\mathrm{Ca}^{2+}$, data not shown), the levels of fluorescence were considerably lower and very similar in both concentrations of Tris (see Figure 5a,b).

In our previous experiments with $S$. typhimurium cells [14], the strongest decrease in $\mathrm{Et}^{+}$fluorescence was observed after the addition of PMB to the suspension of $S$. typhimurium cells in $400 \mathrm{mM}$ Tris $/ \mathrm{HCl}$ buffer. Electrochemical $\mathrm{Et}^{+}$measurements showed that binding of this indicator to DNA is a fast process, and the amount bound is rather stable. In the medium with $1.2 \mu \mathrm{M} \mathrm{Et}^{+}$(see Figure $5 \mathrm{c}$ ), the initial intensity of the fluorescence correlated well with the amount of this cation bound to DNA (Figure 5a,b). In $400 \mathrm{mM}$ Tris $/ \mathrm{HCl}$ buffer, DNA bound to a lower amount of $\mathrm{Et}^{+}$than in $100 \mathrm{mM}$ Tris, and PMB or $\mathrm{Mg}^{2+}$ in the medium decreased the bound amount. $\mathrm{Mg}^{2+}$ or PMB in $100 \mathrm{mM}$ Tris/ $\mathrm{HCl}$ buffer induced a slight time-dependent release of bound $\mathrm{Et}^{+}$(see Figure $5 \mathrm{c}$ ). The addition of PMB to DNA solution in $100 \mathrm{mM}$ Tris buffer at the end of the experiment immediately decreased the amount of bound $\mathrm{Et}^{+}$. However, the effect of PMB addition to a DNA solution in $400 \mathrm{mM}$ Tris was weak, as well as the addition of this polycationic antibiotic to a DNA solution in $100 \mathrm{mM}$ Tris, already containing $\mathrm{Mg}^{2+}$ or PMB (see Figure $5 \mathrm{c}$ ). This demonstrates that ability of PMB to displace $\mathrm{Et}^{+}$depends on the amount of this indicator bound. 

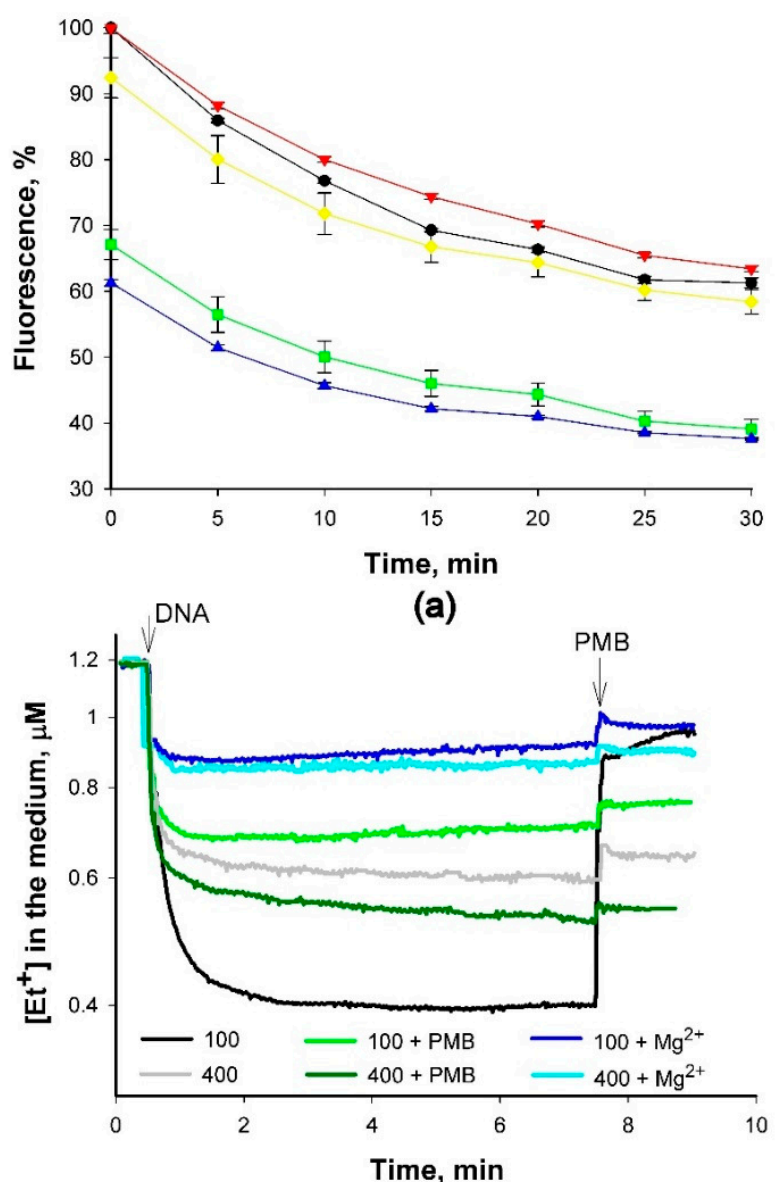

(c)

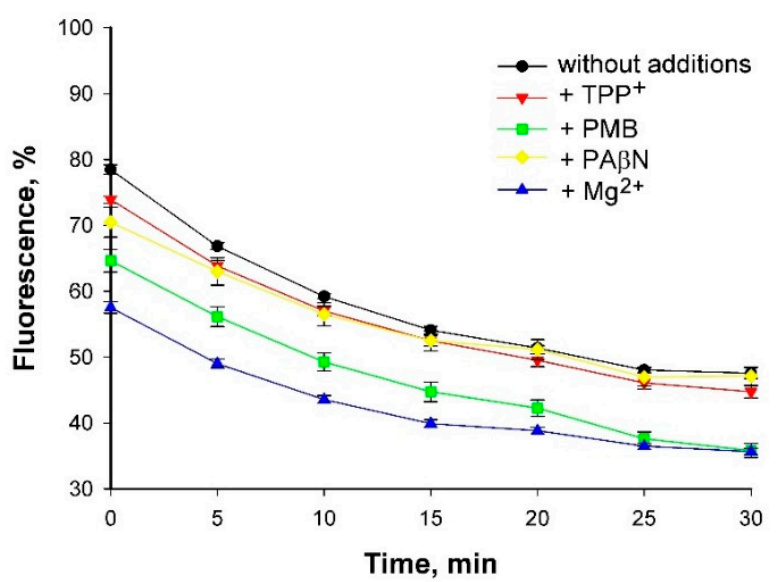

(b)

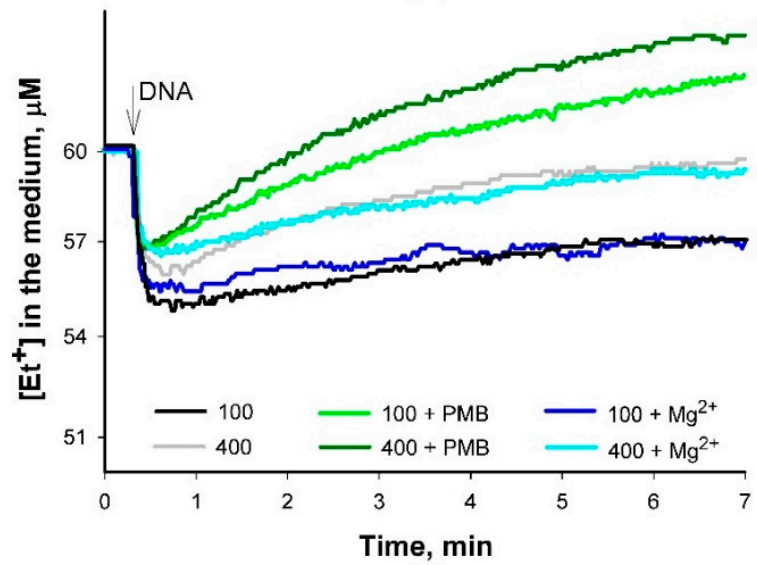

(d)

Figure 5. The influence of the medium composition on the interaction of $\mathrm{Et}^{+}$with DNA. Experiments were performed at $37{ }^{\circ} \mathrm{C}$ in $100 \mathrm{mM}(\mathbf{a}, \mathbf{c}, \mathbf{d})$ or $400 \mathrm{mM}(\mathbf{b}-\mathbf{d})$ Tris $/ \mathrm{HCl}$ buffer, $\mathrm{pH}$ 8. For (a) and (b), 100\% intensity corresponds to the initial level of Et+ fluorescence in DNA solution in $100 \mathrm{mM}$ Tris $/ \mathrm{HCl}$ buffer. The concentration of salmon sperm DNA was $20 \mathrm{mg} / \mathrm{L}$. The initial Et ${ }^{+}$concentration in $(\mathbf{a}-\mathbf{c})$ was $1.2 \mu \mathrm{M}$, in (d) $60 \mu \mathrm{M}$. Concentrations of PA $\beta \mathrm{N}, \mathrm{Mg}^{2+}, \mathrm{TPP}^{+}$and PMB were $250 \mu \mathrm{M}, 10 \mathrm{mM}, 125 \mu \mathrm{M}$ and $100 \mathrm{mg} / \mathrm{L}$, respectively. In c, at the end of the experiment concentration of PMB was increased to $200 \mathrm{mg} / \mathrm{L}$. Label in (b) is valid for (a), also.

However, the binding of $\mathrm{Et}^{+}$to DNA was a partly reversible process when the initial concentration of this indicator was $60 \mu \mathrm{M}$, and a time-dependent release of the initially bound $\mathrm{Et}^{+}$was observed (Figure $5 \mathrm{~d}$ ). In the presence of PMB in $400 \mathrm{mM}$ buffer, the potential of the $\mathrm{Et}^{+}$-selective electrode decreased to values lower than the initial ones before the addition of DNA. These results suggest that some lipophilic cationic compounds were released from salmon sperm DNA as a result of the interaction with PMB.

\section{Discussion}

Antibiotics and other noxious to bacteria compounds are pumped out of the cells by energy-dependent transporters, mainly by proton motive force-driven efflux pumps [1]. The energy-dependent processes in bacteria are sensitive to the conditions of incubation. Different efficiencies and kinetics of the efflux from S. typhimurium wt cells determined at various laboratories $[4,12,14]$ can be explained by different methods of the assay used and, correspondingly, different cell incubation conditions and procedures used during the evaluation of the efflux.

The inhibition of MDR pumps is an attractive way to increase the efficiency of antibiotics. Evaluation of the antibiotic MIC values in the presence of efflux inhibitors is a direct but slow method: it takes 16 and more hours to get the result. Assay of the kinetics of the efflux of indicator compounds is a direct and fast method to determine the capabilities of 
the cells to extrude different xenobiotics, including antibiotics. It takes less than $0.5 \mathrm{~h}$ and provides a possibility to screen the compounds-candidates to efflux inhibitors.

Here, we potentiometrically and fluorimetrically analyzed the efflux in S. typhimurium cells determining the bound amounts of $\mathrm{Et}^{+}$and $\mathrm{TPP}^{+}$. In liquid cultures of Gram-negative bacteria, the electrochemical real-time monitoring of the efflux using $\mathrm{Et}^{+}$and/or $\mathrm{TPP}^{+}$as the indicators, $\mathrm{PA} \beta \mathrm{N}$ as the efflux inhibitor, and PMB as the permeabilizer of the cell envelope is a convenient method. Bacterial suspensions are thermostated and constantly stirred during the experiments, reagents can be added, and the samples taken for complementary analyses without any interruption of the registration and any changes of the incubation conditions.

The proton motive force of bacteria in slightly alkaline media consists in most of $\Delta \psi$ [8]. Despite a high $\Delta \psi$, S. typhimurium wt cells with the intact OM in $100 \mathrm{mM}$ Tris/HCl buffer accumulate neither $\mathrm{TPP}^{+}$nor $\mathrm{Et}^{+}$ions. However, $\triangle$ tolC mutant cells slowly bind these indicators in the absence of the OM permeabilizing compounds, but the presence of EDTA or PMB drastically increases rates of influx (see Figure 1). In the absence of TolC, AcrB or other energy-dependent components of the RND and ABC family, transporters extrude the lipophilic cations to the periplasm instead of the incubation medium, as wt cells do. More efficient accumulation of $\mathrm{Et}^{+}$by $\Delta$ tolC cells before permeabilization of the $\mathrm{OM}$ can be explained by higher selectivity to $\mathrm{TPP}^{+}$of EPs, expressed in the absence of TolC. At low concentrations blocking the activity of RND family pumps, PA $\beta N$ increases the accumulation of indicator cations and stimulates $\mathrm{Et}^{+}$fluorescence. The maximum accumulation of the indicators and the maximum fluorescence of $\mathrm{Et}^{+}$in $\Delta$ tolC mutant cells was achieved at a lower PA $\beta N$ concentration than for wt cells (see Figure $1 b, d$ ). This difference clearly indicates that for inhibition of the efflux, PA $\beta N$ must cross the $O M$, and this crossing is more efficient in the case of mutant. The same tendency was observed also for $\Delta$ AcrB cells [17].

The altered extrusion of $\mathrm{Et}^{+}$ions from cells, lacking the major EP complex MexABOprM, was observed in experiments with Pseudomonas aeruginosa cells [13,18]. Xu and colleagues observed that the intensity of the fluorescence of cells with an inactive MexABOprM pump decreased below the fluorescence in buffer solution when $\mathrm{Et}^{+}$accumulation in the cells reached some "critical" values [18]. This was explained by the degradation of $\mathrm{Et}^{+}$in MexAB-OprM mutant cells or the efflux through the assembly of unknown efflux transporters [18]. The authors were considering ethidium bromide as a non-dissociated neutral molecule, entering the viable bacterial cells by passive diffusion. The possibility to measure $\mathrm{Et}^{+}$by ion-selective electrode indicates that ethidium bromide is dissociated, and near Nernstian behavior of the electrode shows that the degree of dissociation is close to 1. Babayan and Nikaido [13] extracted the cell-accumulated $\mathrm{Et}^{+}$and presented evidence that this indicator is not destroyed by the cells after accumulation. It was concluded that self-quenching is the main reason for the decreased intensity of fluorescence. Our observations agree with the results from the Nikaido group that the accumulated $\mathrm{Et}^{+}$is not degraded by the cells. The self-quenching could be due to the reduction of affinity of DNA to $\mathrm{Et}^{+}$after the binding of a higher amount of this indicator. It is possible that PMB also more efficiently displaces this indicator from the binding sites when the high amount of $\mathrm{Et}^{+}$is bound.

The results of experiments using pure DNA (see Figure 5) suggest that structural and/or functional changes inside the cells during the incubation period alter the DNAbound amount of $\mathrm{Et}^{+}$. When binding equilibrium is reached in DNA solutions containing an excess of $\mathrm{Et}^{+}$, one $\mathrm{Et}^{+}$cation is bound for every five nucleotides in DNA and one per ten nucleotides in RNA molecules [19]. There could be several reasons for fluorescence quenching. According to Hayashi and Harada [20], the intercalation of $\mathrm{Et}^{+}$lengthens and unwinds DNA, and the isotherm of intercalation shows negative cooperativity between adjoining $\mathrm{Et}^{+}$ molecules. On the other hand, a concomitant drop in the intensity of fluorescence without a change in the amount of $\mathrm{Et}^{+}$bound to DNA was observed with an increasing amount of the unbound $\mathrm{Et}^{+}$[21]. In our experiments, a comparison of $\mathrm{Et}^{+}$binding to purified DNA at low $(1.2 \mu \mathrm{M})$ and high $(60 \mu \mathrm{M})$ concentrations of this ion in the medium revealed that 
the release of accumulated $\mathrm{Et}^{+}$to the incubation medium could be the main reason for the decrease in fluorescence at high concentrations of this ion (see Figure 5).

One milligram of the dry weight of Escherichia coli cells contains around $100 \mathrm{nmol}$ of DNA base [22]. Considering that size S. typhimurium chromosome (4857 kbp [23]) is like one of E. coli (4639 kbp [24]), in our experiments, $5 \mathrm{~mL}$ of $S$. typhimurium suspension contained $\sim 150 \mathrm{nmol}$ DNA bases. The maximum intensity of the fluorescence was achieved when the amount of the bound $\mathrm{Et}^{+}$was around $20 \mathrm{nmol}$. It means that the $\mathrm{Et}^{+} / \mathrm{DNA}$ ratio is less than 0.2 , even when we consider also the RNA bases (about $20 \mathrm{nmol}$ in $0.03 \mathrm{mg}$ dry weight cells [22]).

We start to register the increase in fluorescence of $\mathrm{Et}^{+}$simultaneously with the potentiometrically observed influx of this indicator into the cells. It is also indicated that primary binding occurs up to a bound-Et ${ }^{+}$-to-DNA-nucleotide ratio of $0.20-0.25$, and if the $\mathrm{Et}^{+} / \mathrm{DNA}$ ratio is below 0.14, there are no changes in the spectrum [25]. However, we have not detected any threshold for an increase in $\mathrm{Et}^{+}$fluorescence after this indicator binding to DNA. It is possible that the increase in $\mathrm{Et}^{+}$fluorescence starts before it intercalates into DNA. $\mathrm{Et}^{+}$binding to DNA is the ionic strength, as well as medium compositiondependent, and the presence of $\mathrm{Mg}^{2+}$ in the medium decreases the binding of $\mathrm{Et}^{+}$to DNA and the fluorescence of this compound (see Figure 5). The decrease in $\mathrm{Et}^{+}$fluorescence during the incubation with DNA was observed also in the absence of $\mathrm{PMB}$ or $\mathrm{Mg}^{2+}$ (see Figure $5 \mathrm{a}, \mathrm{b})$. This could be because DNA-ethidium complexes become more accessible to water, which is a highly efficient fluorescence quencher [26], and the removal of water increases the fluorescence.

There is evidence of additional non-intercalative, less fluorescence-enhancing sites involving electrostatic binding to nucleic acids. The enhancement of $\mathrm{Et}^{+}$fluorescence observed due to electrostatic binding to DNA or to hydrophobic solvents is attributed to a reduction in the excited state proton transfer rate [19]. However, this secondary binding occurs only at low ionic concentrations (i.e., $0.01 \mathrm{M}$ ) and when binding at the primary site is saturated. Low ionic strength conditions are not typical to the cytosol of viable bacteria, although it could happen after depolarization of the cells when $\mathrm{Et}^{+}$fluorescence in bacterial suspensions is measured in low ionic strength media [11]. However, we must be careful in interpreting these results. Our results indicate (see Figure 2, also [14]) that heat-killed cells bind considerably more $\mathrm{Et}^{+}$than intact cells, despite the very strong accumulation of the cations in the cytosol by membrane potential. These data are in agreement with [27] that fluorescence of metabolically inhibited cells never exceeded more than $50 \%$ of the dead cell values. Most probably, after cell death, the complex nature of bacterial chromosomes [28] is lost, and the relative amount of $\mathrm{Et}^{+}$accessible double-stranded DNA considerably increases.

According to Rodrigues and colleagues [16], at concentrations lower than $3 \mu \mathrm{g} / \mathrm{mL}$ $(7.5 \mu \mathrm{M}), \mathrm{Et}^{+}$does not bind to DNA but already is a substrate of efflux pumps, and such concentrations should be used for studies of the efflux. Results of our experiments indicate that an increase in fluorescence is observed when $\mathrm{Et}^{+}$concentration in the medium is lower, only $3 \mu \mathrm{M}$, and we have not found any concentration threshold for binding of this indicator to DNA. On the other hand, there are ideas that ethidium bromide becomes strongly fluorescent when it gets into the periplasm of Gram-negative bacteria or into the cytoplasm of Gram-positive ones [29].

When cells accumulate a high amount of $\mathrm{Et}^{+}$and fluorescence reaches the maximum level, it stops correlating with the intracellular concentration of this cation, and $\mathrm{Et}^{+}$loses the role of efflux indicator. At increased cell depolarizing concentrations, PA $\beta N$ and PMB cause the release of accumulated $\mathrm{Et}^{+}$. The leakage of $\mathrm{TPP}^{+}$indicates the total depolarization of the $\mathrm{PM}$, but a considerable amount of $\mathrm{Et}^{+}$remains inside the cells, most probably, because of the binding to nucleic acids. Our results indicate that the decrease in intracellular concentration of this cation not immediately leads to the decrease in the fluorescence. It looks that the release of bound $\mathrm{Et}^{+}$is rather a slow process [14]. The fast release of $\mathrm{Et}^{+}$after additions of PA $\beta N$ and PMB agrees with [28] that if $\mathrm{Et}^{+}$is not intercalated between nucleic bases of DNA, it is subject to extrusion or leakage after depolarization of the plasma membrane, 
as in our case. When it is intercalated, the binding constant is sufficiently high to keep $\mathrm{Et}^{+}$from access to the efflux pump systems of the bacterium [19]. The dependence of Polymyxin B-induced $\mathrm{Et}^{+}$binding to the cells on the presence of $\mathrm{PA} \beta \mathrm{N}$ in the medium and the kinetics of $\mathrm{Et}^{+}$binding/release indicate a complex nature of this process. Depending on the concentration used, PMB initially increases the permeability of the OM only and does not affect the PM of gram-negative cells [16]. At higher concentrations, PMB damages the PM and switches off energy-dependent processes, including efflux. When the cell suspension does not contain $\mathrm{PA} \beta \mathrm{N}$ and $\mathrm{Et}^{+}$, fluorescence is not at its maximum, we see the additional $\mathrm{Et}^{+}$accumulation after PMB addition (see Figure 1a,c). The permeabilization of the $\mathrm{OM}$ and switching off the efflux by PMB facilitates $\mathrm{Et}^{+}$entry into the cytosol and binding to DNA, although depolarization of the PM repeals the $\Delta \psi$-dependent $\mathrm{Et}^{+}$accumulationdriving component. However, our previous experiments [14] demonstrated that such $\mathrm{Et}^{+}$ accumulation in S. typhimurium wt cells is only temporary: PMB causes the leakage of $\mathrm{Et}^{+}$after the equilibrium is reached. This means that decreasing fluorescence of $\mathrm{Et}^{+}$after PMB addition is not only because of the self-quenching but also caused by displacement of $\mathrm{Et}^{+}$by PMB at its binding sites. In the presence of EDTA, the effect of PMB on Et ${ }^{+}$ binding is weaker, most probably, because of the reduced binding of PMB to the OM due to EDTA-induced release of LPS [30] (compare curves in Figure 2a,b).

The presence of $\mathrm{PA} \beta \mathrm{N}$ in the cell incubation medium considerably changes the run of events (see Figure $1 \mathrm{~b}, \mathrm{~d}$ ): depolarizing the $\mathrm{PM}$ and causing leakage of $\mathrm{TPP}^{+}, \mathrm{PMB}$ induces the release of more than $50 \%$ of accumulated $\mathrm{Et}^{+}$. How PA $\beta \mathrm{N}$ can so drastically change PMB effects on $\mathrm{Et}^{+}$accumulation? Both compounds have a high affinity to LPS, but PMB added after PA $\beta N$ displaces the latter at the binding sites (Sakalauskaite et al., in preparation). The increased concentration of the free PA $\beta N$, also subsequent added $\mathrm{PMB}$, induces a release of accumulated $\mathrm{Et}^{+}$. The rather stable maximum intensity of the fluorescence in a situation when $50 \%$ of intracellular $\mathrm{Et}^{+}$leaked out supports the idea that the release of DNA-intercalated $\mathrm{Et}^{+}$is a slow process.

\section{Materials and Methods}

\subsection{Bacteria Cultivation and Preparation for Experiments}

Salmonella enterica ser. Typhimurium SL1344 cells of wild type (wt) and $\Delta$ tolC mutant strains were obtained from Prof. Séamus Fanning (Institute of Food and Health, University College Dublin, Ireland). Overnight cultures of these cells were grown in Luria-Bertani broth, containing 0.5\% NaCl (Sigma-Aldrich, Munich, Germany), diluted 1:50 in fresh medium, and the incubation was continued until the $\mathrm{OD}_{600}$ reached 1 . The cells were collected by centrifugation at $4{ }^{\circ} \mathrm{C}$ for $10 \mathrm{~min}$ at $3000 \times g$ (HeraeusTM MegafugeTM 16R, Thermo Scientific, Osterode am Harz, Germany). The pelleted cells were re-suspended in $100 \mathrm{mM}$ Tris-hydroxyaminomethane (Tris)/ HCl (Roth, Karlsruhe, Germany), pH 8.0, to obtain $\sim 2 \times 10^{11}$ cells $/ \mathrm{mL}$. The concentrated cell suspensions were kept on ice until used, but not longer than $4 \mathrm{~h}$. For permeabilization of the outer membrane (OM) during the measurements, ethylene diamine tetraacetic acid (EDTA; Sharlau, Barcelona, Spain), $\mathrm{pH} 8.0$, was added to the final concentration of $1 \mathrm{mM}$. To permeabilize the OM before measurements, the cells were at $37^{\circ} \mathrm{C} 10 \mathrm{~min}$ incubated in $100 \mathrm{mmol} / \mathrm{L}$ Tris $/ \mathrm{HCl}$ containing $10 \mathrm{mmol} / \mathrm{L}$ ethylene diamine tetraacetic acid (EDTA; Sharlau, Barcelona, Spain), pH 8.0, then pelleted and re-suspended as described above. Heat treatment of the cells was performed by incubating $1 \mathrm{~mL}$ of the concentrated suspension in a 1.5-mL Eppendorf tube for $10 \mathrm{~min}$ in a boiling water bath.

\subsection{Potentiometric Measurements}

$\mathrm{TPP}^{+}$and $\mathrm{Et}^{+}$concentrations in the incubation media were potentiometrically monitored using selective electrodes as described previously [14,17]. While assembling $\mathrm{TPP}^{+}$ and $\mathrm{Et}^{+}$-selective electrodes, the sensors were filled with $0.1 \mathrm{mM} \mathrm{TPP}{ }^{+}$chloride (Fluka, St. Gallen, Switzerland) or $\mathrm{Et}^{+}$bromide (Acros Organics, Geel, Belgium) solutions in $100 \mathrm{mM}$ 
$\mathrm{NaCl}$ and connected to internal $\mathrm{Ag} / \mathrm{AgCl}$ half-cell electrodes. In between measurements, the sensors were stored dry at room temperature.

The thermostated and magnetically stirred glass vessels were filled with $5 \mathrm{~mL}$ of $100-$ or $400-\mathrm{mM}$ Tris $/ \mathrm{HCl}, \mathrm{pH} 8.0$, containing $0.1 \%$ glucose. After calibration of the electrodes, the concentrated cell suspension was added to obtain an $\mathrm{OD}_{600}$ of 1 or shared salmon sperm DNA stock solution was added to the final concentration of $20 \mathrm{mg} / \mathrm{L}$. We used the electrode potential-amplifying system with an ultralow-input bias current operational amplifier AD549JH (Analog Devices, Norwood, MA, USA). The data acquisition system PowerLab 8/35 (AD Instruments, Oxford, UK) was used to connect the amplifying system to a computer. The agar salt bridges were used for indirect connection of the $\mathrm{Ag} / \mathrm{AgCl}$ reference electrodes (Thermo Inc., Chelmsford, MA, USA; Orion model 9001) to cell suspensions or DNA solutions in the vessels. The measurements were performed simultaneously in $2-4$ reaction vessels. The $\Delta \psi$ values were calculated as described previously [31], assuming that $\mathrm{OD}_{600} 1$ corresponds to $8.3 \times 10^{8}$ cells $/ \mathrm{mL}, 2.3 \times 10^{9}$ cells correspond to $1 \mathrm{mg}$ of dry mass, and the intracellular water volume of $S$. enterica is $1.1 \mathrm{~mL} / \mathrm{g}$ of dry mass. The representative sets of curves from 3-5 independent series of measurements are presented in figures.

\subsection{Fluorescence Measurements}

Single tube measurements were performed using microtubes with $75 \mu \mathrm{L}$ of samples taken from vessels for electrochemical measurements. The intensity of $\mathrm{Et}^{+}$fluorescence was measured by Modulus ${ }^{\mathrm{TM}}$ Single Tube Reader (Turner BioSystems, Inc., Sunnyvale, CA, USA) using a green filter set (excitation $525 \mathrm{~nm}$, emission 580-640 nm).

For evaluation of $\mathrm{Et}^{+}$interaction with sheared salmon sperm DNA (Eppendorf AG, Hamburg, Germany), stock solutions of PA $\beta N$ hydrochloride, Polymyxin B (PMB) sulphate (7730 U of PMB base/mg; Sigma-Aldrich, Munich, Germany), $\mathrm{TPP}^{+}$chloride, or $\mathrm{MgCl}_{2}$ (Roth, Karlsruhe, Germany) were added to the incubation buffer and mixed. Then salmon sperm DNA solution was added to the final concentration of $20 \mathrm{mg} / \mathrm{L}$ and $\mathrm{Et}^{+}$to the corresponding concentration. The samples were mixed and transferred into 96-well flatbottom black plates, $100 \mu \mathrm{L}$ per well. The relative intensity of the fluorescence (excitation $535 \mathrm{~nm}$, emission $612 \mathrm{~nm}$ ) was monitored in the "TECAN GENios Pro ${ }^{\mathrm{TM}}$ " (Männedorf, Switzerland) plate reader, thermostatting the plate at $37^{\circ} \mathrm{C}$. The plate was shaken $5 \mathrm{~s}$ before each registration point.

\section{Conclusions}

Electrochemical monitoring of the concentration of lipophilic indicators provides information on the kinetics of efflux and serves as an express method for studies of the efficiency of these transporters. Inhibiting the activity of efflux, PA $\beta N$, the most popular inhibitor of RND family pumps, increases the accumulation of $\mathrm{Et}^{+}$and $\mathrm{TPP}^{+}$in the cells and stimulates $\mathrm{Et}^{+}$fluorescence. Lower concentrations of PA $\beta \mathrm{N}$ are needed to reach the maximal level of accumulation of lipophilic cations in the case of $\Delta$ tolC mutant than wt cells. Electrochemical measurements indicate that the main reason for decreasing $\mathrm{Et}^{+}$ fluorescence at high concentrations of this ion is the release of accumulated $\mathrm{Et}^{+}$to the incubation medium. However, at the maximum level of $\mathrm{Et}^{+}$fluorescence, $\mathrm{PA} \beta \mathrm{N}$, as well as $\mathrm{PMB}$, cause the leakage of $\mathrm{Et}^{+}$ions from the cytosol depolarizing their plasma membrane, but this leakage is not considerably affecting $\mathrm{Et}^{+}$fluorescence. $\mathrm{Et}^{+}$binding to DNA is medium ionic strength, as well as the composition-dependent, and the presence of PMB or $\mathrm{Mg}^{2+}$ in the medium decreases it. The intensity of fluorescence reaches the saturation level and stops reacting to the intracellular concentration of this indicator when cells accumulate a high amount of $\mathrm{Et}^{+}$.

Author Contributions: Author contribution statement: Conceived and designed the project R.D., S.S. and V.M. Performed the experiments and acquired the data, S.S. and V.M. Wrote the paper S.S. and R.D. All authors have read and approved the final version submitted for publication. 
Funding: This work was supported by the Research Council of Lithuania; funding grant No MIP040/2015 to R.D.

Institutional Review Board Statement: Not applicable.

Informed Consent Statement: Not applicable.

Acknowledgments: We are grateful to Séamus Fanning (Institute of Food and Health, University College Dublin, Ireland) for providing Salmonella enterica ser. Typhimurium SL1344 and $\Delta$ tolC mutant cells.

Conflicts of Interest: The authors declare no conflict of interest.

Sample Availability: Not available.

\section{References}

1. Du, D.; Wang-Kan, X.; Neuberger, A.; van Veen, H.W.; Pos, K.M.; Piddock, L.J.V.; Luisi, B.F. Multidrug efflux pumps: Structure, function and regulation. Nat. Rev. Microbiol. 2018, 16, 523-539. [CrossRef]

2. Wang, Z.; Fan, G.; Hryc, C.F.; Corey, F.; Blaza, J.N.; Serysheva, I.I.; Schmid, M.F.; Chiu, W.; Luisi, B.F.; Du, D. An allosteric transport mechanism for the AcrAB-TolC multidrug efflux pump. eLife 2017, 6, 1-19. [CrossRef]

3. Gros, P.; Talbot, F.; Tang-Wai, D.; Bibi, E.; Kaback, H.R. Lipophilic cations: A group of model substrates for the multidrug-resistance transporter. Biochemistry 1992, 31, 1992-1998. [CrossRef]

4. Blair, J.M.A.; Piddock, L.J.V. How to measure export via bacterial multidrug resistance efflux pumps. mBio 2016, 7, e00840-16. [CrossRef] [PubMed]

5. Daugelavicius, R.; Buivydas, A.; Sencilo, A.; Bamford, D.H. Assessment of the activity of RND-type multidrug efflux pumps in Pseudomonas aeruginosa using tetraphenylphosphonium ions. Int. J. Antimicrob. Agents 2010, 36, 234-238. [CrossRef] [PubMed]

6. Martins, A.; Spengler, G.; Rodrigues, L.; Rodrigues, G.; Viveiros, L.; Ramos, J.; Martins, M.; Couto, I.; Fanning, S.; Pages, J.-M.; et al. $\mathrm{pH}$ Modulation of efflux pump activity of multi-drug resistant Escherichia coli: Protection during its passage and eventual colonization of the colon. PLoS ONE 2009, 4, e6656. [CrossRef] [PubMed]

7. Hockings, P.D.; Rogers, P.J. The measurement of transmembrane electrical potential with lipophilic cations. Biochim. Biophys. Acta 1996, 1282, 101-106. [CrossRef]

8. Nicholls, D.G.; Ferguson, S. Bioenergetics, 4th ed.; Elsevier Ltd.: Amsterdam, The Netherlands, 2013.

9. Severini, A.; Richard Morgan, A. An assay for proteinases and their inhibitors based on DNA/ethidium bromide fluorescence. Anal. Biochem. 1991, 193, 83-89. [CrossRef]

10. Martins, A.; MacHado, L.; Costa, S.; Cerca, P.; Spengler, G.; Viveiros, M.; Amaral, L. Role of calcium in the efflux system of Escherichia coli. Int. J. Antimicrob. Agents 2011, 37, 410-414. [CrossRef]

11. Amaral, L.; Cerca, P.; Spengler, G.; MacHado, L.; Martins, A.; Couto, I.; Viveiros, M.; Fanning, S.; Pages, J.M. Ethidium bromide efflux by Salmonella: Modulation by metabolic energy, $\mathrm{pH}$, ions and phenothiazines. Int. J. Antimicrob. Agents 2011, 38, 140-145. [CrossRef]

12. Anbazhagan, P.V.; Thavitiki, P.R.; Varra MAnnamalai, L.; Putturu, R.; Lakkineni, V.R.; Pesingi, P.K. Evaluation of efflux pump activity of multidrug-resistant Salmonella typhimurium isolated from poultry wet markets in India. Infect. Drug Resist. 2019, 12, 1081-1088. [CrossRef] [PubMed]

13. Babayan, A.; Nikaido, H. In Pseudomonas aeruginosa ethidium bromide does not induce its own degradation or the assembly of pumps involved in its efflux. Biochem. Biophys. Res. Commun. 2004, 324, 1065-1068. [CrossRef] [PubMed]

14. Mikalayeva, V.; Sakalauskaitè, S.; Daugelavičius, R. Interaction of ethidium and tetraphenylphosphonium cations with Salmonella enterica cells. Medicina (Lithuania) 2017, 53, 122-130. [CrossRef]

15. Rodrigues, L.; Wagner, D.; Viveiros, M.; Sampaio, D.; Couto, I.; Vavra, M.; Kern, W.V.; Amaral, L. Thioridazine and chlorpromazine inhibition of ethidium bromide efflux in Mycobacterium avium and Mycobacterium smegmatis. J. Antimicrob. Chemoth. 2008, 61, 1076-1082. [CrossRef]

16. Daugelavicius, R.; Bakiene, E.; Bamford, D.H. Stages of polymyxin B interaction with the Escherichia coli cell envelope. Antimicrob. Agents Chem. 2000, 44, 2969-2978. [CrossRef]

17. Sutkuvienè, S.; Mikalayeva, V.; Pavan, S.; Berti, F.; Daugelavičius, R. Evaluation of the Efficiency of Synthesized Efflux Pump Inhibitors on Salmonella enterica ser. Typhimurium Cells. Chem. Biol. Drug Des. 2013, 82, 438-445. [CrossRef]

18. Xu, X.H.N.; Wan, Q.; Kyriacou, S.V.; Brownlow, W.J.; Nowak, M.E. Direct observation of substrate induction of resistance mechanism in Pseudomonas aeruginosa using single live cell imaging. Biochem. Biophys. Res. Commun. 2003, 305, 941-949. [CrossRef]

19. Lepecq, J.B.; Paoletti, C. A fluorescent complex between ethidium bromide and nucleic acids: Physical-chemical characterization. J. Mol. Biol. 1967, 27, 87-106. [CrossRef]

20. Hayashi, M.; Harada, Y. Direct observation of the reversible unwinding of a single DNA molecule caused by the intercalation of ethidium bromide. Nucleic Acids Res. 2007, 35, e125. [CrossRef] [PubMed] 
21. Heller, D.P.; Greenstock, C.L. Fluorescence lifetime analysis of DNA intercalated ethidium bromide and quenching by free dye. Biophys. Chem. 1994, 50, 305-312. [CrossRef]

22. Neidhardt, F.C.; Curtiss III, R.; Ingraham, J.L.; Lin, E.C.C.; Low, K.B.; Magasanik, B.; Reznikoff, W.S.; Riley, M.; Schaechter, M.; Umbarger, H.E. Escherichia coli and Salmonella: Cellular and Molecular Biology, 2nd ed.; ASM Press: Washington, DC, USA, 1996.

23. McClelland, M.; Sanderson, K.E.; Spieth, J.; Thomson, N.R.; Pickard, D.; Wain, J.; Churcher, C.; Mungall, K.L.; Bentley, S.D.; Holden, M.T.G.; et al. Complete genome sequence of Salmonella enterica serovar Typhimurium LT2. Nature 2001, 413, 852-856. [CrossRef]

24. Goeden, D.J.R.; Shao, B.M.Y.; Glasner, D.; Rode, C.K.; Mayhew, G.F.; Gregor, J.; Davis, N.W.; Kirkpatrick, H.A.; Frederick, M.A.; Blattner, R.; et al. The Complete Genome Sequence of Escherichia coli K-12. Science 1997, 277, 1453-1462. [CrossRef]

25. Martz, W.W. The Interaction of Ethidium Bromide with Nucleic Acids, Ecommons. 1971. Available online: https:/ / ecommons. luc.edu/luc_diss/1149 (accessed on 12 April 2021).

26. Vardevanyan, P.O.; Antonyan, A.P.; Parsadanyan, M.A.; Davtyan, H.G.; Karapetyan, A.T. The binding of ethidium bromide with DNA: Interaction with single- and double-stranded structures. Exp. Mol. Med. 2003, 35, 527-533. [CrossRef] [PubMed]

27. Jernaes, M.W.; Steen, H.B. Staining of Escherichia coli for flow cytometry: Influx and efflux of ethidium bromide. Cytometry 1994, 17, 302-309. [CrossRef]

28. Badrinarayanan, A.; Le, T.B.K.; Laub, M.T. Bacterial chromosome organization and segregation. Annu. Rev. Cell Dev. Biol. 2015, 31, 171-199. [CrossRef] [PubMed]

29. Rodrigues, L.; Ramos, J.; Couto, I.; Amaral, L.; Viveiros, M. Ethidium bromide transport across Mycobacterium smegmatis cell-wall : Correlation with antibiotic resistance. BMC Microbiol. 2011, 11, 35. [CrossRef] [PubMed]

30. Marvin, H.J.; ter Beest, M.B.; Witholt, B. Release of outer membrane fragments from wild-type Escherichia coli and from several E. coli lipopolysaccharide mutants by EDTA and heat shock treatments. J. Bacteriol. 1989, 171, 5262-5267. [CrossRef] [PubMed]

31. Daugelavicius, R.; Bamford, J.K.; Bamford, D.H. Changes in host cell energetics in response to bacteriophage PRD1 DNA entry. J. Bacteriol. 1997, 179, 5203-5210. [CrossRef] 